\title{
The Politics of Public Health: A Response to Epstein
}

Lawrence O. Gostin

Georgetown University Law Center, gostin@law.georgetown.edu

Maxwell Gregg Bloche

Georgetown University Law Center, bloche@law.georgetown.edu

This paper can be downloaded free of charge from:

https://scholarship.law.georgetown.edu/facpub/724

46 Persp. Biology \& Med. S160-S175 (Supp. 2003)

This open-access article is brought to you by the Georgetown Law Library. Posted with permission of the author. Follow this and additional works at: https://scholarship.law.georgetown.edu/facpub

Part of the Health Law and Policy Commons, Health Policy Commons, Law and Politics Commons, and the Public Health Commons 


\title{
THE POLITICS OF PUBLIC \\ HEALTH
}

\author{
a response to Epstein
}

\section{LAWRENCE O. Gostin* AND M. GREgG BLOCHE†}

\begin{abstract}
Conservatives are taking aim at the field of public health, targeting its efforts to understand and control environmental and social causes of disease. Richard Epstein and others contend that these efforts in fact undermine people's health and well-being by eroding people's incentives to create economic value. Public health, they argue, should stick to its traditional task-the struggle against infectious diseases. Because markets are not up to the task of controlling the transmission of infectious disease, Epstein says, coercive government action is required. But market incentives, not state action, he asserts, represent our best hope for controlling the chronic illnesses that are the main causes of death in industrialized nations. In this article, we assess Epstein's case. We consider his claims about the market's capabilities and limits, the roles of personal choice and social influences in spreading disease, and the relationship between health and economic inequality. We argue that Epstein's critique of public health overreaches, oversimplifies, and veils his political and moral preferences behind seemingly objective claims about the economics of disease control and the determinants of disease spread. Public health policy requires political and moral choices, but these choices should be transparent.
\end{abstract}

\footnotetext{
^Professor of Law, Georgetown University; Professor of Public Health, Johns Hopkins University; and Director of the Center for Law and the Public's Health.

†Professor of Law, Georgetown University, and Adjunct Professor of Public Health, Johns Hopkins University.

Correspondence: Lawrence O. Gostin, Professor of Law, Georgetown University Law Center, 600 New Jersey Avenue, Washington, DC 20001.

Email: gostin@law.georgetown.edu.

The authors gratefully acknowledge support from the Centers for Disease Control and Prevention, the Alfred P. Sloan Foundation, and a Robert Wood Johnson Foundation Investigator Award in Health Policy Research.
}

Perspectives in Biology and Medicine, volume 46, number 3 supplement (summer 2003):S160-S175

(C) 2003 by The Johns Hopkins University Press 
D ichard Epstein does nOt "DO" euphemism. He holds that a "moral phiR losophy of false comradeship" keeps us from selling human organs to high bidders, that law should let hospitals "just say no" when poor people seek lifesaving care for self-inflicted harm, and that public financing of medical care for the elderly is a bad idea (Epstein 1997, pp. 102-3, 282). ${ }^{1}$ Most health and safety regulation, he says, imperils our health by trimming incentives to produce wealth. And, well, as the Cat in the Hat says, "that is not all."

Epstein's prose provokes; it does not pander. And it challenges proponents of government activism in the health sphere to consider consequences they do not intend and contradictions they would rather ignore. For the most part, political liberals have not done so. Epstein's central claim, in his essay in this volume (Epstein 2003) and in his other writing on health and medicine, is that regulation entails covert and coerced cross-subsidies that reduce our collective well-being by diminishing our range of choices and our motivation to create value. Often, he observes, these cross-subsidies are regressive: they transfer value from the worse-off to the better-off in ways that fit awkwardly with their benevolent intent. Sometimes, he charges, these subsidy schemes have a darker purpose: they benefit politically potent actors at the expense of those less empowered.

These criticisms drive political liberals to distraction because they are so at odds with liberals' self-understanding. Proponents of public activism on behalf of people's health do not like to see themselves as undermining human health, wellbeing, or freedom. But Epstein's criticisms have analytic bite. A diverse range of well-meaning regulatory measures in the health sphere imposes cross-subsidies that might meet stiff resistance if administered more openly, through the tax system. Requirements that hospitals provide free care to the uninsured operate through cross-subsidies from insured patients - cross-subsidies that burden lower and middle-class working people more heavily than they do wealthier Americans (Bloche 1995). Protections afforded by the Americans with Disabilities Act impose costs that burden firms' shareholders, customers, and employees. And, as Epstein notes, the costs of liability for harm ensuing from vaccines and pharmaceuticals are born by consumers, making these products less accessible.

Advocates of a robust state role in the health sphere ought to take such concerns more seriously. But Epstein overshoots the mark when he condemns virtually all contemporary health regulation on these grounds. Epstein far outruns his empirical supply lines, and his judgments as to when markets do and don't work well rest on unstated moral assumptions. These assumptions also animate his distinctions between autonomous and coerced conduct, and they lie behind his attributions of causal responsibility. Taken together, these assumptions consti-

\footnotetext{
${ }^{1}$ For Epstein, "self-inflicted harm" encompasses not just drug and alcohol abuse, street violence, and the like, but also such slip-ups as diabetic patients' failure to test their blood glucose levels. Epstein opposes Medicare "in the abstract" but cites "transition problems" as reason for not ending this program.
} 
tute an alternative morality of public health. This morality is largely libertarian, but it tends toward social conservatism in matters of intimate conduct. It departs sharply from the contemporary public health movement's preferences for distributive equity and for a non-judgmental approach to people's intimate behavior. These differences are political, and they should be debated and resolved openly, in the political arena. They cannot be finessed through assertions about the presence or absence of market failure, coercion, or causal responsibility.

In what follows, we develop this line of argument. We begin by taking issue with Epstein's sharp distinction between the "new" and the "old" public health. We agree with Epstein that public health practitioners' policy prescriptions have evolved considerably since the 19 th century, but we ascribe this to shifting patterns of illness and to 20th-century concerns about social equity, not to antimarket attitudes run amok. We then probe his claims about the scope of market failure, the influences that do and do not constitute coercion, and the causation of ill health. Finally, we raise concerns about his essay's overgeneralization from fair points to panoramic claims.

\section{is There A "NeW" Public Health?}

We agree with Epstein that there is a "new" public health, broader in its reach than was the 19th-century emphasis on control of infectious disease. This "new" public health encompasses both a research agenda and a commitment to apply scientific findings in the public sphere to reduce the social burdens of disease (Gostin 2000, 2002). We believe that public health professionals, legislators, and regulatory bodies should craft evidence-based responses to contemporary health risks, provided that these responses balance the benefits of improved health against potential economic costs and impositions on personal liberty. These responses also need to take account of the comparative advantages of market and regulatory mechanisms. Moreover, policymakers should acknowledge inevitable trade-offs between short-term and long-term benefits (and costs).

The relationships between health, human freedom, and social and economic well-being are extraordinarily complex. As Epstein observes, strong evidence supports a causal connection between population-wide wealth and health. But money by itself does not make people healthy; it works by expanding and improving people's possibilities and capabilities - their educational and employment opportunities, their physical and social environments, and perhaps even their subjective sense of well-being (Sen 1999). So how resources are spent matters enormously. The "new" public health seeks to gather and employ scientific evidence to guide this spending - to direct it rationally toward disease prevention, environmental protection, and social investments that promote health by broadening people's options and capabilities. The "new" public health does not profess to put health ahead of other social purposes. It acknowledges that people weigh health against other ends when making both market and political 
choices. Neither does the "new" public health claim trump authority in all policy matters that touch upon health and disease. It concedes the equal and often greater relevance of other sources of knowledge and ways of understanding when society faces policy questions with health implications. It does, on the other hand, offer political decision-makers a large and growing body of evidence on the health consequences of alternative social and legal arrangements.

Epstein objects to this set of endeavors by creating a caricature-by spinning the story of public health's evolution and the law's response so as to portray the "new" as a radical departure from the "old."We acknowledge that there has been change since the 19th century-in disease risks and in the public values by which market outcomes are politically judged. But what has not changed is public health's commitment to promoting the health of populations by scientifically proven and economically feasible means. A state-of-the-art account of the "new" public health appears in a recent report by the Institute of Medicine (IOM), The Future of the Public's Health in the 21st Century (2002; see also Gostin, Boufford, and Martinez 2003). This report proposes an agenda for government and private action to improve population-wide health. It calls for: (1) an improved state public health infrastructure (e.g., workforce, laboratories, and data systems); (2) programs aimed at scientifically proven determinants of population health; and (3) wider private sector engagement in health promotion (encompassing business, academia, the media, and community institutions).

Public health researchers and commentators point to the mismatch between government spending on medical services and medical care's modest influence on population health. More than 95 percent of federal and state health dollars are spent on medical care and research, and only 1 to 2 percent is directed toward prevention (Boufford and Lee 2001; Eilbert et al. 1996). Paltry levels of public spending on population-wide health programs have left public health agencies in "disarray," unable to effectively conduct health promotion and disease prevention programs (IOM 1988, 1996a, 1996b, 2002). Yet there is much evidence that access to medical care is less important as a determinant of health than are behavioral and environmental factors (McGinnis and Foege 1993). Epidemiological studies have identified strong correlations between population-wide health status and a variety of social, physical, and economic conditions of life. Research aimed at explaining these correlations is ongoing and highly promising. To the extent that this research yields opportunities for action to promote health at low cost, by comparison with medical services, it should appeal to proponents of parsimony in public spending.

Instead of expanding government's role in response to these opportunities, the "new" public health calls upon private actors to share the work of health promotion. The IOM's report on the future of public health points both to political constraints on public intervention and to the importance of private actors in shaping social and environmental conditions that influence health. The IOM identified five private sector categories: health care institutions, business enter- 
prises, the mass media, academia, and community groups. To be sure, the "new" public health is broader in its reach than the 19th-century public health agenda Epstein would prefer: it looks beyond control of infectious disease to physical, social, economic, and other environmental risk factors for illness more generally (IOM 1988; Petersen and Lupton 1996; Tulchinsky and Varvikova 2000). ${ }^{2}$ But this larger agenda reflects changes that Epstein underplays, including the growing impact of chronic illness, the suppression of once-fearsome infectious diseases, and our deepened understanding of environmental determinants of illhealth.

It is unsurprising that public health regulation in 19th- and early 20th-century America focused on prevention and control of infectious disease-and that judicial review of such regulation deferred so readily to government action to control contagion. As Epstein notes, the alacrity of infectious disease transmission and the impossibility of tracing the sources of infection case-by-case precluded effective legal governance of the risks of airborne and waterborne illness through a system of private rights and duties. Judicial acceptance of such measures as quarantine and mandatory vaccination made sense even amidst a laissezfaire ethos, because neither private law nor market incentives could manage the externality problems arising from contagion. Until the antibiotic revolution of the 1930s and 1940s, infectious diseases were, by far, the dominant threats to the public's health and security (Duffy 1990; McNeill 1976). During the Civil War, two-thirds of Union Army deaths and three-quarters of Confederate Army deaths were due to infectious disease. Migration to cities during the early industrial era created conditions ripe for disease transmission-overcrowded slums, homelessness, infestations, and squalor (Fee 1997). Epidemics of smallpox, cholera, measles, diphtheria, typhoid fever, and influenza recurred unpredictably, killing thousands.

This existential threat, cognizable in economic terms as a problem of uncontrolled externalities, gave rise to the idea of a public law response to health danger. Legislatures and agencies targeted living conditions and vectors of disease transmission. Regulatory measures addressed cleanliness and hygiene; these included inspections, sanitary requirements, and nuisance abatement (Novak 1996). Regulation also targeted behaviors associated with disease transmission. It compelled such measures as vaccination, testing and screening, partner notification, and, in the extreme, isolation and quarantine. These 19th- and early 20thcentury regulatory interventions laid a legal foundation for later public responses to health risks that raised externality and other market failure issues.

As the threat of infectious diseases waned and as concern about cardiovascu-

\footnotetext{
${ }^{2}$ Different commentators have employed the term "new" public health in different ways (Petersen and Lupton 1996). But these uses of the term share our emphasis on the multiple environmental and life circumstances that shape people's health, and on the importance of broad-based private as well as public action to promote health.
} 
lar disease, cancer, diabetes, and other chronic diseases mounted, health researchers and policymakers looked to build on this foundation. The leading causes of death in the United States today are heart disease, cancer, cerebrovascular diseases, chronic respiratory illnesses (principally asthma, bronchitis, and emphysema), and unintentional injuries (National Center for Health Statistics 2002). The "new" public health targets their "upstream" causes (McGinnis and Foege 1993). A sedentary lifestyle and poor eating habits contribute to obesity, a risk factor for four of the leading causes of mortality (Friedman 2000; Mokdad et al. 2003; NCCDPHP 2002; Siegel et al. 1993). ${ }^{3}$ Exposure to toxic substances in the environment and the workplace also contributes to the leading causes of morbidity and mortality, especially cancer and chronic respiratory diseases. Smoking, the most important preventable cause of death in America, is a potent risk factor for cardiac and other vascular disease, cancer, and chronic respiratory illnesses (NCCDPHP 2003).

Epstein treats public health's efforts to target these "upstream" factors through public law as a radical departure from its 19th-century focus on contagion. Whereas he stresses the differences, we see similarities. Today, as in the 19th century, public health aspires to lower population-wide risk by identifying and addressing the largest influences on morbidity and mortality. The epidemiological transition from infectious disease to chronic disease arising from lifestyles and environmental exposure has shifted the focus of public health research and action from contagion to people's social and physical environments. Policy proposals that have ensued from this new emphasis aim, for the most part, to empower people to make healthy choices. Stated in economic language, externality problems remain an important basis for public intervention: examples include environmental toxins, insufficient time and space for exercise, and nutritionally inadequate food in public schools. But many of the regulatory measures urged by proponents of the "new" public health address other market failures, including insufficient information about health risks and, more controversially, economic actors' ability to influence people's preferences through symbols of fashion, "cool," and sensuality (Gostin 2000).

\section{The POLITICS OF MARKeT FAILURE}

Epstein's challenge to the "new" public health relies heavily on his claim that it calls for government intervention not justified by genuine market failure. But market failure can be discerned only by reference to some normative conception of what markets are supposed to achieve. Standard accounts of the rationale for regulation refer to a variety of market failures, including positive and negative externalities, inadequate information, and moral hazard (Breyer 1980). Ex-

\footnotetext{
${ }^{3}$ Approximately 65 percent of Americans over 20 years old are overweight, and 30.5 percent are obese.
} 
ternalities, though, can be identified and assayed only by reference to moral or political judgments about what should count as a social good (or bad) and how these goods (and bads) should be valued. Whether an actor has enough information to make an informed, autonomous choice is a moral — not an exclusively empirical-question (Bloche 2003). And assessment of the waste induced by socalled "moral hazard," the propensity of people to demand more of something when they bear less than its full cost, is not possible without a normative judgment about how much of the thing they should ideally demand (Bloche 2003).

Epstein makes many such normative judgments; he just doesn't acknowledge them. We highlight several to illustrate the point. He criticizes laws barring employment and health insurance discrimination against people living with HIV/ AIDS on the ground that these laws compel cross-subsidies for risky behavior (e.g., intravenous drug use and unprotected sex), thereby lowering its social price (moral hazard) and increasing its incidence. On the other hand, he rejects the idea of liability for fast-food chains for selling dangerously fatty meals on the ground that consumers should exercise self-restraint. He thus allows fast-food firms to benefit from moral hazard (by imposing much of the social cost of serving dangerous food on others), while rejecting anti-discrimination laws' creation of moral hazard in the form of a diminished social price for sex and drug use that spread HIV infection.

Only underlying moral judgment can explain this apparent inconsistency. People who have risky, unconventional sex or who abuse drugs should bear the full social price of their behavior-or perhaps even an inflated price, insofar as employment or health insurance discrimination is based on exaggerated expectations of medical risk and cost. But firms that entice consumers to eat life-endangering food should be able to pass much of the social price of doing so onto these consumers. Discerning cross-subsidies here, as elsewhere, is a normative endeavor that builds on baseline premises about the proper scope of personal (and corporate) responsibility.

Another example is Epstein's critique of occupational health and safety regulation, a critique he roots in regulators' limited abilities to anticipate potential consequences of their actions (Epstein 2003). ${ }^{4} \mathrm{He}$ chides occupational health regulators for acting based on worst case risk scenarios-for "proceed[ing] under the banners 'better safe than sorry' or 'best to err on the side of safety"' (Epstein 2003). Citing Nichols and Zeckhauser (1986), he warns of the "perils of prudence" - the likelihood that over-regulation of remote risks not only wastes money but increases risk by bringing about unanticipated consequences. Yet he endorses morals regulation directed at sexual sin, by invoking the precautionary

\footnotetext{
${ }^{4}$ Epstein indicates his preference for governance of occupational health risks via contracts between employers and workers, a preference tied to his skepticism about regulators' ability to do better than employees at anticipating the potential health and financial consequences of alternative risk management arrangements.
} 
rationale that he condemns in the occupational health context. In the 19th century, he says, "prostitution, fornication, adultery, homosexuality, sodomy, bestiality, bigamy, polygamy, and incest" posed unknown risks of contagion. These uncertain risks, he suggests, justified regulatory proscriptions against sexual sin "even in the absence of specific knowledge of the mechanisms of [disease] transmission." Likewise, traditional morals laws, targeting places of "sinful" sex, could have slowed the spread of AIDS before its mechanisms of contagion became known. Making "clear evidence of disease transmission" a prerequisite for shutting down centers of promiscuous sex risked loss of the chance to gain control of a deadly epidemic at an early stage. "All this suggests," he writes, "that the critical time for preventive measures is before the risk is fully understood" (Epstein 2003).

There are arguments for and against erring on the side of safety when the mechanisms and magnitude of risks are uncertain. Critics of environmental law's "precautionary principle," which embodies the prudence Epstein disparages in the occupational health sphere, point to the difficult-to-calculate opportunity costs of prudence (Morris 2000). They also highlight the problem of wholly unanticipated risks - a problem that "precautionary" policy toward uncertain but known risks fails to address. Epstein does not explore the theoretical basis or empirical support for these arguments. Instead, he alternately disparages and endorses the precautionary approach, in a fashion that correlates tightly with whether regulation targets business firms' risk-creating conduct or people's intimate behavior. Nowhere does he declare that regulatory policy in the health sphere ought to embody either Lochnerian deference to economic power or traditional Judeo-Christian sexual morality. ${ }^{5}$ But nowhere does he explain the patent inconsistency in his treatment of the precautionary approach.

\section{The politics of Personal Responsibility}

Ascriptions of personal responsibility and distinctions between autonomous and coerced conduct play a central role in Epstein's challenge to the "new" public health's approach to public law. His allegations of oppressive and inefficient regulatory cross-subsidy rest on his premises about the scope of personal responsibility - premises infused with moral preferences he does not acknowledge.

Moral judgment about the scope of individual responsibility is not objectionable; to the contrary, it is the stuff of much of politics and law. As Hannah Arendt (1994), among others, has observed, justice would be an outmoded institution were it not for our willingness to assign individual culpability despite our ability to explain behavior in deterministic terms. Health researchers and poli-

\footnotetext{
${ }^{5}$ See Lochner v. New York (1905), which holds that a New York law setting minimum work hours for bakers violated the due process clause of the 14th Amendment. Lochner came to stand for the Supreme Court's emphasis on freedom of contract, as a matter of form, without regard for disparities of economic power.
} 
cymakers make a category mistake by treating scientific understandings of environmental, behavioral, and other determinants of disease as grounds for rejecting personal responsibility. A high-profile case-in-point was the 1996 contretemps over presidential candidate Robert Dole's assertion that smoking is voluntary, not addictive (New York Times 1996). Dole backed away from this claim (which the press covered as a campaign gaffe) in the face of criticism that it contravened prevailing medical understanding. But Dole had a point: the availability of a deterministic account of smoking ("it is addictive") does not require people to embrace this account in the political or legal realms. Scientific understandings are substrates, not substitutes, for political and legal judgments.

Indeed, people often adhere at the same time, in the therapeutic and public realms, to deterministic and autonomy-regarding accounts of problematic human conduct. Individuals seek treatment, or are referred to it, for myriad behaviors that the law treats as matters of personal responsibility (Brandt and Rozin 1997). ${ }^{6}$ Researchers seek social, psychological, and even biological explanations for the most horrific human actions, yet civilization holds their perpetrators accountable in settings like Nuremberg and The Hague. Ascription of personal responsibility involves moral judgment, and often a measure of politics, in matters of health and disease as in other realms. And here, Epstein hides the ball.

For example, he treats risky sex with multiple partners as something fomented by "sinful" institutions, such as gay bathhouses, but he treats risky eating as a matter of personal choice. "It is harsh, counterproductive, and unwise," he says, "to go after individuals for their sexual practices," but at supermarkets and fast food outlets, "children and their parents should be able to exercise some degree of self-restraint” (Epstein 2003). Epstein's moral rationale for this distinction escapes us, but the moral consequence-culpability for an institution at the social fringe and non-accountability for businesses in the American mainstream-is clear.

By insulating uninhibited coupling, but not eating, from ascription of personal responsibility, Epstein takes aim at the infamous bathhouses while putting sellers of high-risk food beyond the law's reach. Bathhouses, not their sex-craving patrons, he holds, were responsible for the early spread of HIV. Government should have closed them, since the state should target "institutions that facilitate harmful interactions with adverse third-party health effects." But McDonalds is not responsible, Epstein asserts, when fat-craving diners order fries and McNuggets steeped in artery-clogging oils. ${ }^{7}$ McDonalds' patrons are responsible-they should exercise "self-restraint"—and holding the firm liable for serving risky meals is therefore wrong. Encouraging sex that kills is unacceptable, but promoting food that kills is unexceptionable.

\footnotetext{
${ }^{6}$ In addition to smoking, examples include overeating, sexual infidelity, domestic violence, pedophilia, and gambling.

${ }^{7}$ For a vivid description of the high-fat and other unhealthy additives that may make McNuggets more hazardous than consumers reasonably expect, see Pelman v. McDonald's (2003).
} 
This is moral politics, not moral reasoning, and it drives Epstein's charge that liability for selling risky meals would levy an oppressive, inefficient cross-subsidy. Since people choose to eat McNuggets, he holds, the higher price they would pay to cover tort damages constitutes a cross-subsidy from fit calorie-counters to the corpulent, who are more likely to get sick and to die-and to sue. Those who overindulge should bear the costs that come with their choice; thus this cross-subsidy is inefficient, since it passes part of the cost of overindulgence from those who incur it to calorie-counters who show restraint. ${ }^{8}$

\section{THE POLITICS of CAUSATION}

Epstein's conclusions about cause and effect play an equally important role in his critique of the "new" public health's uses of public authority. His claims of causal connection, like his ascriptions of personal responsibility, undergird his opposition to government measures that reach beyond control of contagious disease. And, like his judgments about responsibility, his ideas about causal connection (and its absence) are animated by moral content he is disinclined to acknowledge.

Epidemiologists, like other scientists, tend to understand causation as a complex web of interactions between prior phenomena-a web of interactions that make the occurrence under study more (or less) likely. In theory, the sum total of these interactions determines whether the occurrence under study does or does not happen. In practice, the scientific method cannot study the sum total of these interactions, all at once. At best, scientists can craft simplified models of these interactions, then examine one or a few of these interactions at a time, by controlling all variables except for a small number. By this plodding method, epidemiologists come up with correlations and with probabilities of causal relationships (IOM 2001; Karasek 1990; Kunzli 2002; Pearce and Davey-Smith 2003; Rice and Atkin 2000; van Poppel and van der Heijden 1997). ${ }^{9}$ They can

\footnotetext{
${ }^{8}$ One could easily offer an analogous assessment of the shutdown of gay bathhouses. By making it harder-more costly — for gay men to couple with multiple partners, shutting down the bathhouses burdens promiscuous gay men who have "safe sex" and thus pose minimal risk of spreading HIV. Through their greater inconvenience or diminished sexual pleasure, these men bear part of the cost of an AIDS prevention strategy that does not discriminate based on the differential risks posed by different bathhouse patrons. They thereby cross-subsidize, in effect, disease-free sexual partners (and intravenous drug abusers) "downstream" from gay men who would have dangerous sex with more partners were the bathhouses to remain open. Epstein's failure to offer this assessment reflects his disinclination to treat sex-seeking bathhouse patrons as accountable choosers—and his disinclination to give much weight to sexual inconvenience and diminished sexual pleasure as costs. Our own agreement with the policy of bathhouse closure reflects our sympathy with these underlying judgments. Our only point here is that Epstein must render such judgments, at least tacitly, in order to avoid treating bathhouse shutdown as a case of nettlesome cross-subsidization.

${ }^{9}$ Research data exist to support policy initiatives relating to each of the key determinants of health: the natural environment-e.g., clean air, water, and other natural resources-and the physical or built environment-e.g., transportation, buildings, green spaces, and roads. These findings are
} 
disprove causal relationships, but they cannot definitively discern them. Based on this fragmentary evidence, health professionals and policymakers play the percentages, by targeting (through therapeutic or regulatory intervention) one or a few of the most likely causal interactions.

Inevitably, political, cultural, and moral influences shape the selection of targets. And, inevitably, tensions between these influences engender conflict over target choice. AIDS prevention is the most bitterly contested case: debates over condom and clean needle distribution, closing down places of promiscuous sex, and promotion of abstinence versus safe sex are illustrative (Gostin 2003). Controversies over tobacco liability, restrictions on cigarette marketing, and the prospect of liability for sale of artery-clogging foods are other examples. Public health activists err by rejecting any role for politics and moral judgment in the selection of disease prevention strategies. The entry of politics and morals into health promotion is inevitable, and debate over the cultural and moral matters at stake is, we think, an appropriate part of health policymaking in a democratic society. Epstein all but ignores this scientific and political complexity. In its place, he proclaims simply that something is or is not a cause of disease, and that policymakers should intervene or restrain themselves, accordingly. He nowhere acknowledges the moral content of these conclusions-conclusions that happen to correlate closely with his politics. An example is his acceptance of social factors as causes of the AIDS epidemic, in conjunction with his dismissal of their relevance for obesity and its health consequences. "Sinful" bathhouses, excesses of "associational freedom," and failure of monogamous commitment are causal factors and appropriate targets of legal intervention, he holds. But corporate promotion of fattening foods and couch potato habits is not responsible for obesity (in either the scientific or legal sense); individuals bring it upon themselves, through their consumptive choices. ${ }^{10}$

Likewise, Epstein's broad-brush dismissal of hypothesized causal connections between socio-economic disadvantage and ill-health overlooks nuance in transparent pursuit of his opposition to redistributive policies. He notes, as have we, that population-wide health status correlates with overall income, that public policies that shrink society-wide wealth risk reducing population health, and that aggressive redistribution of wealth erodes incentives that spur growth and thereby improve health (Bloche 2001b). He also points to a correlation between enduring income inequality and dramatic improvements in infant mortality rates in England over the past century (Epstein 2003). But he ignores evidence that

\footnotetext{
embedded within an influential ecologic theory that characteristics of places-neighborhoods, schools, work sites, etc.—carry with them health risks for people who live or work there.

${ }^{10}$ To be sure, he says that "people are more likely to eat to excess if others around them do so first," but he dismisses this as "influence," not "coercion," and suggests that this influence may cut the other way. Awareness that others are imperiling themselves, he says, "may spur" some to take greater care of themselves.
} 
societies with similar mean incomes differ widely in their performance on standard measures of population health. (Sen 1999; Wilkinson 1996). There is lively debate over whether poorer performance on population health measures correlates with steeper society-wide gradients in personal income (Kawachi and Kennedy 1997; Mellor and Milyo 2001). It is well-established, however, that societies with higher levels of absolute deprivation - that is, higher proportions of people too poor to create and purchase healthful conditions of life-fare worse on population health indices (House 2001). ${ }^{11}$ And it is also well-established that among nations with similar mean incomes, those with recent histories of higher investment in education, public health programs, and other social infrastructure perform much better on measures of population health (Sen 1999).

This suggestive but incomplete evidence points toward a research agenda that might shed light on how public policy can more effectively promote health and human well-being. How does being at the bottom end of the income scale undermine health? Is the problem mainly one of consumer buying power-access to decent food, housing, and other material goods? Or does diminished access to education and employment opportunities play a crucial role, and might public intervention in this realm be a better investment, dollar for dollar, than provision of material goods? To what extent does the psychosocial stress of life at the bottom end make poorer people sicker? And to what extent do both poor health and low socioeconomic standing flow from third factors - maladaptive behavior, perhaps (Deaton 2002)? ${ }^{12}$ Finally, there is a large challenge here for development economists. It is one thing to say, as we and Epstein do, that incentives arising from income inequality spur economic growth, and that growth, in general, promotes population-wide health. It is another, much more difficult task, to understand how, and to what degree, different profiles of income inequality engender different kinds, as well as rates, of growth. And it is yet another, equally challenging task to specify the connections between different types and rates of growth and people's health and well-being.

The deepening of our understanding along these lines will require both robust empirical research and reflective debate about values, goals, and present and future trade-offs. Political conservatives eschew this enterprise because it promises to enhance the potential of the activist state. And we concede that expanding the domain of public health to encompass the socioeconomic conditions for

\footnotetext{
${ }^{11}$ This effect is believed to operate both through inadequate individual (and family) buying power and through the tendency of societies with higher proportions of socioeconomically disadvantaged people to provide lower levels of such health-enhancing public goods as education, sanitation, and recreational space.

${ }^{12}$ The poor, some suggest, may have worse health because of genetic differences, behavior, or reduced access to health care or education. Or perhaps the causal relationship works in the other direction: poor health could lower income through diminished ability to work or higher medical costs.
} 
human well-being raises questions of overreach. Not only do public health researchers and professionals lack the needed multidisciplinary expertise, but the knowledge they do have does not give them standing to specify public values or limits on state intrusiveness. These are tasks for politics. But public health research can and should inform the politics of socioeconomic equity, as well as the politics of personal responsibility.

Health researchers and professionals err by treating health as a trump value: society sacrifices health in the service of liberty and myriad aesthetic and other ends. Yet health matters enormously in our lives and our politics. Mounting proof of the social and environmental determinants of illness has the potential to move Americans toward support for a more activist state. Epstein and other conservatives fear this prospect as both a threat to economic liberty and a feeding opportunity for interest groups positioned to use state power for parochial ends (Gingrich 2001). ${ }^{13}$ They could best cope with these concerns-and check activist excess - by engaging the available evidence more rigorously than they have so far.

\section{CONCLUSION}

The "new" public health is less coercive, in the conventional sense, than its 19thcentury regulatory antecedents. It eschews physical compulsion, such as quarantine and coerced therapy, except as a last-ditch step, and it sees synergies between health promotion and respect for human rights (Bloche 2001a; Mann et al. 1994). It has been much influenced by the bioethics revolution of the 1960s and 1970s, which made personal autonomy the prime directive in medical matters (Rothman 1992), and it has been much criticized for this, especially in the AIDS context.

The "new" public health has raised political conservatives' ire, though, by extending its reach beyond the traditional domain of infectious disease to social and economic influences on population-wide health. In so doing, it has inquired into causal connections between ill-health and such powerful institutions as tobacco companies, industrial polluters, firearm manufacturers, and fast-food chains. Although Epstein levies the charge that it has resorted to state coercion in this sphere, it has in fact employed state power in limited fashion. To be sure, government has resorted to command-and-control regulation in the environmental and occupational safety realms. ${ }^{14}$ But the state's approach to the con-

\footnotetext{
${ }^{13}$ Conservative icon Newt Gingrich has taken on proponents of a connection between economic inequality and ill-health, charging that efforts by public health researchers to document such connections constitute an attack on the free enterprise system.

${ }^{14}$ One might add consumer purchase of pharmaceuticals and medical devices to this list, but Epstein does not complain about command-and-control regulation in this realm, perhaps because it long predates the late 20th-century regulatory endeavors he targets in his essay.
} 
sumer has been quite restrained. With trivial exceptions, such as seatbelt and motorcycle helmet requirements, the law has sought to promote information flow and to persuade-rather than compel_consumers to behave safely. Warning requirements for cigarettes and alcohol, restrictions on advertising, and campaigns encouraging healthy eating and discouraging smoking have been the mode. ${ }^{15}$ Suits against tobacco companies by victims of smoking-related illnesses have mostly failed, ironically because of warning requirements.

More threatening by far, for political conservatives, is the "new" public health's attention to social and economic determinants of illness and well-being. A promotional leaflet for an American Enterprise Institute forum on putative links between income inequality and health warned in 2001 of the topic's "farreaching implications such as the restructuring of important sections of our economic system.' We doubt that revolution is impending, but growing evidence of connections between social conditions and health could give social fairness new force as a political issue. Americans are more tolerant of disparities in wealth than they are of inequalities in health. In economics language, they tend to see health as a "merit want" - something to be distributed more equitably than goods allocated based on the prevailing distribution of wealth. To the extent they see health as tied to wealth, economic disparities could emerge as suspect. The future course of research in this area could prove politically decisive. If it confirms and clarifies a close connection between social disadvantage and health, it could become the "new" public health's principal public policy legacy.

\section{REFERENCES}

Arendt, H. 1994. Eichmann in Jerusalem: A report on the banality of evil. New York: Penguin. Bloche, M. G. 1995. Health policy below the waterline: Medical care and the charitable exemption. Minn. Law Rev. 80: 299-405.

Bloche, M. G. 2001a. Caretakers and collaborators. Cambridge Q. Healthcare Ethics 10: 275-84.

Bloche, M. G. 2001b. Remarks at the American Enterprise Institute Forum, Is Inequality Bad for Our Health? 11 Oct. Available at <http://www.aei.org/events/eventID.48/ transcript.asp.> Accessed 28 Feb. 2003.

Bloche, M. G. 2003. The invention of health law. Calif. Law Rev. 91(2).

Boufford, J. I., and P. R. Lee. 2001. Health policies for the 21st century: Challenges and recommendations for the U.S. Department of Health and Human Services. New York: Milbank Memorial Fund.

Brandt, A. M., and P. Rozin, eds. 1997. Morality and health. New York: Routledge.

Breyer, S. 1980. Regulation and its reform. Cambridge: Harvard Univ. Press.

Deaton, A. 2002. Policy implications of the gradient of health and wealth. Health Aff. 21: 13-30.

\footnotetext{
${ }^{15}$ Epstein finds "coercion" in recommended "tables of ideal weights," but this is an idiosyncratic usage in his part: no legal consequences attach to weighing more than the tables recommend.
} 
Duffy, J. 1990. The sanatarians: A history of American public health. Urbana: Univ. of Illinois Press.

Eilbert, K.W., et al. 1996. Measuring expenditures for essential public health services. Washington, DC: Public Health Foundation.

Epstein, R. A. 1997. Mortal peril: Our inalienable right to health care? Reading, MA: Addison Wesley.

Epstein, R. A. 2003. Let the shoemaker stick to his last: A defense of the "old" public health. Perspect. Biol. Med. 46(Suppl.):S138-S159.

Fee, E. 1997. The origins and development of public health in the United States. In Oxford textbook of public health, 3rd ed., ed. R. Detels et al., 35-54. Oxford: Oxford Univ. Press.

Friedman, J. M. 2000. Obesity in the new millennium. Nature 404:632-34.

Gingrich, N. 2001. Remarks at the American Enterprise Institute Forum, Is Inequality Bad for Our Health? 11 Oct. Available at <http://www.aei.org/events/eventID.48/ transcript.asp.> Accessed 28 Feb. 2003.

Gostin, L. O. 2000. Public health law: Power, duty, restraint. Berkeley: Univ. of California Press.

Gostin, L. O. 2002. Public health law and ethics: A reader. Berkeley: Univ. of California Press.

Gostin, L. O. 2003. The AIDS pandemic: Complacency, injustice, and unfulfilled expectations. Chapel Hill: Univ. of North Carolina Press.

Gostin, L. O., J. I. Boufford, and R. Martinez. In press. The future of the public's health: Vision and values. J. Law Med. Ethics.

House, J. 2001. Relating social inequalities in health and income. J. Health Polit. Policy Law 26:523-32.

Institute of Medicine (IOM). 1988. The future of public health. Washington, DC: National Academy Press.

Institute of Medicine (IOM). 1996a. Healthy communities: New partnerships for the future of public health. Washington, DC: National Academy Press.

Institute of Medicine (IOM). 1996b. Using performance monitoring to improve community health: Exploring the issues. Washington, DC: National Academy Press.

Institute of Medicine (IOM). 1997. Improving health in the community: A role for performance monitoring. Washington, DC: National Academy Press.

Institute of Medicine (IOM). 2001. Rebuilding the unity of health and the environment: A new vision of environmental health for the 21st century. Washington, DC: National Academy Press.

Institute of Medicine (IOM). 2002. The future of the public's health in the 21st century. Washington, DC: National Academy Press.

Karasek, T. T. 1990. Healthy work. New York: Basic Books.

Kawachi, I., and B. Kennedy. 1997. Health and social cohesion: Why care about income inequality? BMJ 314:1037-40.

Kunzli, N. 2002. The public health relevance of air pollution abatement. Eur. Respir. J. 20(1):198-209.

Lochner v. New York, 198 U.S. 45 (1905).

Mann, J., et al. 1994. Health and human rights. J. Health Human Rights 1:6-22.

McGinnis, J. M., and W. H. Foege. 1993. Actual causes of death in the United States. JAMA 270:2207-12. 
McNeill, W. H. 1976. Plagues and peoples. New York: Anchor Books.

Mellor, J., and J. Milyo. 2001. Reexamining the evidence of an ecological association between income inequality and health. J. Health Polit. Policy Law 26:487-532.

Mokdad, A. H., et al. 2003. Prevalence of obesity, diabetes, and obesity-related risk factors, 2001. JAMA 289:76-79.

Morris, J., ed. 2000. Rethinking risk and the precautionary principle. Burlington, MA: Butterworth-Heinemann.

National Center for Chronic Disease Prevention and Health Promotion (NCCDPHP). 2002. Factors contributing to obesity: Biological, behavioral, and environmental factors associated with overweight and obesity. Centers for Disease Control and Prevention (CDC), U.S. Dept. of Health and Human Services. Available at <http://www.cdc.gov/nccdphp/dnpa/obesity/contributing_factors.htm.> Accessed 26 Feb. 2003.

National Center for Chronic Disease Prevention and Health Promotion (NCCDPHP). 2003. Targeting tobacco use: The nation's leading cause of death. Centers for Disease Control and Prevention (CDC), U.S. Dept. of Health and Human Services. Available at <http://www.cdc.gov/nccdphp/aag/aag_osh.htm.> Accessed 26 Feb. 2003.

National Center for Health Statistics. 2002. Health, United States, 2002. Tables 32, 70, and 71. Available at <http://www.cdc.gov/nchs/products/pubs/pubd/hus/02tables. htm.> Accessed 10 Jan. 2003.

New York Times. 1996. Clinton assails Dole on tobacco and liquor company on TV ads. Editorial. Available at <http://query.nytimes.com/search/article-page.html?res= 9C0CEEDC1439F935A25755C0A960958260.> Accessed 26 Feb. 2003.

Nichols, A. L., and R. J. Zeckhauser. 1986. The perils of prudence: How conservative risk assessments distort regulation. Regulation 10:13-24.

Novak, W. J. 1996. The people's welfare: Law and regulation in nineteenth century America. Chapel Hill: Univ. of North Carolina Press.

Pearce, N., and G. Davey-Smith. 2003. Is social capital the key to inequalities in health? Am. J. Public Health 93:122-29.

Pelman v. McDonald's, S.D. NY (2003).

Petersen, A., and D. Lupton. 1996. The new public health: Health and self in the age of risk. London: Sage.

Rice, R. E., and C. K. Atkin, eds. 2000. Public communication campaigns. Newbury Park, CA: Sage.

Rothman, D. 1992. Strangers at the bedside: A history of how law and bioethics transformed medical decision making. New York: Basic Books.

Sen, A. 1999. Development as freedom. New York: Knopf.

Siegel, P. Z., et al., 1993. Stroke mortality and its socioeconomic, racial, and behavioral correlates in Florida. Public Health Rep. 108:454-58.

Tulchinsky T. H., and E. A.Varavikova. 2000. The new public health: An introduction for the 21st century. San Diego: Academic Press.

van Poppel, F., and C. van der Heijden. 1997. The effects of water supply on infant and childhood mortality: A review of historical evidence. Health Transitions Rev. 7(2):11348.

Wilkinson, R. 1996. Unhealthy societies: The affliction of inequality. New York: Routledge. 